\title{
LHOMME L'Homme
}

Revue française d'anthropologie

$170 \mid 2004$

Espèces d'objets

\section{On Recognizing Things}

The "Ethnic Artefact" and the "Ethnographic Object"

Johannes Fabian

\section{(2) OpenEdition \\ Journals}

Electronic version

URL: http://journals.openedition.org//homme/24789

DOI: 10.4000/Ihomme.24789

ISSN: 1953-8103

Publisher

Éditions de l'EHESS

\section{Printed version}

Date of publication: 1 June 2004

Number of pages: 47-60

ISSN: 0439-4216

\section{Electronic reference}

Johannes Fabian, « On Recognizing Things », L'Homme [Online], 170 | 2004, Online since 01 January 2006, connection on 30 April 2019. URL : http://journals.openedition.org/lhomme/24789 ; DOI :

10.4000/lhomme.24789 


\section{On Recognizing Things \\ The "Ethnic Artefact" and the "Ethnographic Object"}

Johannes Fabian

S

OME TIME AGO, I formulated a sweeping critique of how anthropology makes its object, the Other (Fabian 1983). Here I would like to offer some thoughts on interesting connections between the Other as object and «other objects ». Before I get again to the Other as object, toward the end of this paper, I want to reflect on the construction of otherness in objects. Behind this is a dialectical move which, though not consciously planned, took me from a totalizing conception of the object of anthropological discourse to an interest in the role particular objects, things as well as artefacts, have played in the history of Western encounters with an Other.

It has been both satisfying and daunting to realize that many colleagues seem to have travelled similar roads. Anthropological theorizing and empirical research on material culture, for decades maligned as a marginal, rather boring relict from our nineteenth-century beginnings, have had a spectacular essor, as witnessed by some of the most interesting works to come out in recent years (Appadurai 1986, Miller 1987, Stocking 1985, Thomas 1991) ${ }^{1}$. Future historians will have to sort out the reasons for such renewed interest, but it is already clear that there is a connection between the crisis and critique of anthropological writing and the critique of ethnographic exhibitions. Both reveal an underlying crisis of ethnographic representation (Fabian 1991 : ch. 11). Who would have predicted, during the two or three decades between the 1950s and the 1970s when

This essay goes back to a paper delivered at a workshop on " Modern Culture and the Ethnic Artefact », organized by Ákos Moravánsky at the Internationales Forschungszentrum Kulturwissenschaften, Vienna, August 28-31, 1996. It was recently published in German (Fabian 2002) and a Slovak version appeared a few years ago (Fabian 1998a).

1. An outstanding example is the essay on "Objects of Ethnography " by Barbara KirschenblattGimblett (1998: 17-78). 
modern anthropology had its heyday, that ethnological museums would become the sites of hot debates and political turmoil, which they are today, perhaps precisely because modern anthropology had all but forgotten ethnic artefacts ${ }^{2}$ ?

In my own work I have been concerned with objects in two contexts. One of them was a study of popular genre painting in Zaire. It was the discovery of paintings as objects, their physical presence in African living rooms, their status of a commodity that had its market within the urban population of Shaba/Katanga, that caused me to consider their ethnographic significance ${ }^{3}$. Here I would like to concentrate on some of the problems I have been facing in another project : a study of material, bodily aspects of the beginnings of modern exploration and ethnography in Central Africa. Among the material mediations of knowledge, I consider early "ethnographic " collecting (Fabian 1998b, reprinted in Fabian 2001: ch. 7). I am trying to understand its aesthetics, economics, and especially its epistemological significance. What kind of knowledge, I want to ask, comes from such objects? Or, more accurately: what kind of knowledge do we need to bring along in order to recognize things as collectible objects and how does our encounter with objects transform such knowledge ${ }^{4}$ ?

The questions I just formulated are about cognition as well as pragmatics, about science as well as politics. Pursuit of scientific knowledge through collecting was a practice established (in various branches of "natural history" and in a long tradition of "curiosity " [Pomian 1987; Stagl 1995]) before Euro-American explorers began to collect what, at the latest by the middle of the 19th century, was referred to as «ethnographic objects" (a curious term that will have our attention later). Also clear is that ethnographic collecting was a political practice inasmuch as it was instrumental in gaining intelligence about territories and populations which were targeted for imperial rule: objects identified tribes and cultural units which eventually served to establish colonial boundaries and administrative subdivisions. We find in colonial discourse a certain internationalism that flaunted its humanitarian or philanthropic motives but was a thin disguise for national interests. The nation state was, from the beginning, a political as well as an epistemic frame connecting the practices of ethnic and ethnographic collecting and, indeed, the emerging dis-

2. Elements of the debate on ethnic artefacts are also discussed in archeology - a discipline that in many countries has close links, intellectual and institutional, with anthropology (especially in the growing branch of " historical archeology " that includes such special fields as industrial archeology). 3. Fabian 1996, see also an earlier essay on relations between contemporary popular African painting and folk art (Fabian \& Szombati-Fabian 1980).

4. All this became part of an exploration of the explorers' minds, a book that also incorporates parts of this paper (Fabian 2000 : especially ch. 8). 
ciplines of folklore and ethnology. If that is so, then the current interest that makes of "objects" an object of debate should be tempered by the insight that we are treading on deep historical ground.

One way to probe that history is to recall a distinction between two kinds of collectibles : ethnic artefacts and ethnographic objects. Naming the distinction raises a terminological issue that is likely to affect, and perhaps complicate, our discussion. One could decide to treat artefact and object as synonyms, but the two terms may actually signal quite different discourses. As I understand it, artefact, etymologically and in its practical connotations, is essentially a narrative and often an aesthetic concept; narrative, in that an artefact is a thing that tells the history of its production and aesthetic, in that it was made by, or with, art. Artefacts are things that belong to culture rather than nature; they are, to use another deep rooted distinction, the business of Geisteswissenschaften rather than Naturwissenschaften. Now, and this is the point were matters get complicated and interesting, there can be no doubt that things called ethnographic objects - artefacts by their nature - were, within the paradigms of emerging anthropology (evolutionism and diffusionism, the warring twins), treated as objects of the kind science needs in order to operate its methods. They were studied by a discipline, ethnology, that may have thought of itself as a Kulturwissenschaft, but adopted methodologies that had their origins in positivist "natural history». Spatial distribution and taxonomic classification dominated the agendas of research and theorizing about culture. Animal traps, house types, textiles, but also rituals, myths, kinship systems, and forms of government were treated comme des choses. It is interesting to note that diffusionists, though they were as taxonomic as they come, hence fixed on (square) "tabular space" (Foucault), preferred the image of Kreise, circles, whereas their evolutionist adversaries thought in terms of lines. Kreis, of course, is not only a geometrical concept; it has social connotations as a circumference containing people who share certain goods, certain kinds of information or interest (Georg Simmel had analyzed Kreise in his sociology). And that calls up another concept crucial in theorizing about objects : objects may, as commodities, circulate within "spheres" or circuits by which they are determinated (valued) and which they determinate.

Thinking about ethnic artefacts and ethnographic objects teaches us that the two discourses we evoked - the human and the natural sciences - do not coexist peacefully. Their contrasting and contradictory claims can be disentangled, up to a point, when they are confronted with the question of recognition in the production of knowledge. I came to think about recognition while working through the 19th century travelogues I mentioned earlier. 
I found many striking examples of explorers recognizing the familiar in landscapes they had never seen before, or the ordinary in extraordinary practices they witnessed for the first time; even to African persons in whom they saw savages most of the time they would occasionally give recognition ${ }^{5}$.

What about recognizing African artefacts? As far as I can tell, the travelogues expressed recognition in two major forms: through subsumption and collection. First a brief word on subsumption. One of the most powerful and enduring categories ever to be invented in the encounter between Europe and Africa has been the fetish ${ }^{6}$. Things that were somehow striking in themselves or appeared strange in the context in which they were found, objects whose function was not understood or, if it was understood, not approved, were designated as fetishes. The cognitive interest in using the term was less to classify things than to classify people, or rather to place people on the other side of a demarcation line separating the civilized from the savage. Yet there was always also a rest of recognition in the sense that fetishes were experienced as "devilish" objects; they were dangerous and therefore to be respected as long as the European beholders lacked the power to destroy them.

Interest in classifying people is what talk about fetishes and talk about ethnographic objects had in common. The two discourses, by the way, coexisted for a quite a while. Many of the travellers among my sources use the term fetish without compunction. Things identified as fetishes were collected as ethnographic evidence ; conversely, things collected as ethnographic evidence were often depicted in illustrations or exhibited in museums as fetishes. Actually, to make matters still more complicated, there was, at least in English, another term available and widely used, with a semantic position somewhere between fetish and ethnographic object: the curio, a noncommittal term for things collected en passant.

Most of the earlier travellers who produced the accounts I studied collected African objects but this was only one of their "scientific" assignments. At the latest by the mid-1880s, or shortly before the colonial boundaries were established at the Berlin conference of 1884-1885, we also get incidental reports of objects being bought by enterprising Europeans, either for private collections, or in the hope to find institutional customers. By 1905, or so, some of the famous expeditions to the interior of the Congo - Leo Frobenius, Emil Torday, Samuel P. Verner, Herbert Lang and James Chapin (see Schildkrout \& Keim 1990 and 1998) - had collecting of ethnographica as their main ostensible purpose or preoccupation.

5. For examples of several connotations of recognition, especially those that suggest connections between knowing others and remembering them, see Fabian 1999, and 2000 : 226-233.

6. See the essays by William Pietz on this subject $(1985,1987,1988)$. 
"Ostensible ", because the image someone like Frobenius projected - that of a rather single-minded object-chaser who spoiled the market by paying too much - may hide the fact that "scientific » collecting of objects, to use an apt expression coined by Nicholas Thomas, was always " entangled " in a complex net of purposes, practices, and processes. To stay with the example of Frobenius, while rounding up and transporting objects dominated the logistics of his travels, and while he conducted ethnographic studies (including the collection of oral data on history, religion, and the verbal arts) the most urgent task of his expedition was the gathering of geographical and economic information (as stated explicitly in the title of his work, see Frobenius 1907). Exporting rubber or ivory and shipping ethnograpic collections to Europe had processes of commodification and market relations as their common denominator.

An unexpected finding I came up with is that phrases such as "ethnographic object" or "ethnographic collection" were generally used by the 1870s and that, to my knowledge, no one stopped to ponder how odd a usage this is. How can an object or a collection be "ethnographic? " $I$, the object, does not write (-graphic from graphein); the ethnographer writes, ethnography is what he or she does (ethnography as a term for field research) and produces (ethnography as the written report) ${ }^{7}$. But while there was no rhyme in this, there was reason. The point is that, whereas to designate things as fetishes expresses a certain kind of recognition, however mistaken and perverted, talk of ethnographic objects belongs to a discourse that makes recognition irrelevant, because it purports to get along without a subject that could either give or deny recognition. This is why James Clifford, one of the most influential contributors to recent anthropological theorizing about objects, collecting, and exhibition, pleads for restituting the status of fetishes to ethnographic objects as a token of their recognition ${ }^{8}$.

To have been ethnographically collected, that is, removed from its context of production and consumption, is of the essence of the ethnographic object. As a scientific object it has its function, not as a keepsake or souvenir, nor as a token of experience or memory, or as a curio arousing curiosity or causing amusement, but as an item to be placed in systems of classification and taxonomic description ${ }^{9}$. Strictly speaking, the absence of

7. On uses of "ethnographic", see Fabian 1991: ch. 11. On "textualizing objects", see Kirschenblatt-Gimblett 1998:30-34.

8. See Clifford $1985: 244$, and especially also what Kramer (1990:44-46) says about bestürztes Wiedererkennen, "startled recognition ", that is, recognition one was not planning to give, in the transformation of fetishes into art.

9. That memory and classification may, nevertheless, be connected is shown in paper on ethnographic display in the 19th century by Dias (1994) and in a delightful experiment conducted by the staff and students of the Institute for Ethnology and African Studies at the University of Mainz (Kohl 1996). 
context, lamented by museum curators for practical reasons, and by modern critics of exhibitions, for theoretical ones, is not a problem with ethnographic objects ; it is, as it were, their condition of possibility. If the demands for context were met, things that figure as ethnographic objects would be "scientifically" useless ${ }^{10}$. Notice that this argument is analogous to one that holds for critiques of structuralist methods in linguistics and beyond. Structuralist methodology is reproached for neglecting context. But removing the units of analysis from their context (from meaning, from pragmatic, rhetorical, or aesthetic functions) is what makes structuralist analysis work. We may have reasons to reject such removal but, in that case, our critique must be addressed to the premises of structuralism, not to its consequences.

Collecting artefacts, resulting in decontextualization, is what established the study of material culture, old style. It was a science and its methods were attractive for the study of culture in general because human artefacts that were not things in any literal sense (myths, songs, rituals, institutions, beliefs) could be treated like objects. This sort of reification, to return to my sources, sometimes comes out in revealing expressions. Leo Frobenius, Africanist and collector of renown, in a few pages of advice to future collectors, referred to Kuba artefacts as "ethnologischer Kram", "ethnological stuff» $(1907: 238)$, called their sacred objects "heiliger Kram " ("sacred stuff »), reported on the market for " ethnographic stuff », ("ethnographischer Kram »), and spoke of Luba oral lore as "legend-stuff" ("Legendenkram») (ibid. : 351, 355, 356). This may have been just condescending talk to which Frobenius was prone; at the same time it reveals an intellectual operation that consisted in imagining or presenting African material culture as amorphous until submitted to scientific analysis.

This basic stance toward ethnographic objects was maintained by the same explorers/collectors who were eager to demonstrate their capacity to recognize differences and grant distinction. Even in the very short version presented here, the story of the ethnographic object and its collection during the exploration of Central Africa would be incomplete without at least mentioning its transformation into art. None of the authors I read were on the look-out for aesthetic qualities in the objects they gathered. Yet, at some point "ethnographic stuff ", at least some of it, became African art. As we are slowly getting to know that process, we can begin to think about

10. Although I believe that what I say about context remains valid for the present argument I should like to point to a valuable distinction Barbara Kirschenblatt-Gimblett (1998:19-23) makes between "in situ " qualifying relations between objects and their original setting as "metonymic" and «context» as a presumably «metaphorical» interpretive construct. See also my paper on the perils of context in ethnography (Fabian 1995, reprinted in Fabian $2001:$ ch. 2, and in a recent collection on the problem of context edited by Dilley 1999). 
what kind of recognition this transformation entailed. So much seems to be certain ${ }^{11}$ : for all but a few admirers of African art, the aesthetic significance of these objects was, much like their scientific significance, predicated on their removal from context. Conversely, we find that collectors, such as Frobenius and Torday who were at least temporarily exposed to the context in which they found their objects, remained reluctant when it came to recognizing "ethnographic stuff " as art (see Fabian 2001 : ch. 7). Frobenius (1907: 248) occasionally speaks of "Kunst» ("Art») in captions to illustrated objects but in the text he designates objects sold to him as "Kunstgewerbeartikel» ("artisanal items»). Emil Torday, collector of Kuba royal statues that became icons of African art, uses the term "Art " in the subtitle of one of his books but relativizes this in the heading of a chapter largely devoted to collected objects when he speaks of « arts and crafts » $(1925: \text { ch. } 19 \text {; notice also the late date of that publication })^{12}$.

I spoke of material culture studies, old style. Significantly, material culture, new style, got its start by emphasizing the very materiality of human artefacts as something demanding recognition, as objects, human subjects and communities run into, hurt themselves against, in processes of objectification which are constitutive of Self and Society ${ }^{13}$. It is no coincidence that an anthropology of the body and of sensual experience emerged together with, or at least alongside, modern material culture studies ${ }^{14}$. These developments, I believe, give us a theoretical perspective from which the human artefact can be approached and from which - to return to the specific question this essay set out to address - critical insights regarding the distinction of ethnic and ethnographic objects may be gained.

I begin with an observation on a trait which ethnic and ethnographic objects have in common and which may justify assigning to them a common label, such as ethnic artefact. In both cases materiality plays a central though somewhat baffling role. On the one hand, it seems almost tautological to affirm that ethnic artefacts are material objects. Yet it is worth pondering why, although ethnic music and dance, ethnic poetry, and story telling have also been the target of collecting, we don't really have these

11. On the many ways this transformation from object to work of art occurred see, for instance, Clifford's critical review of the Primitivism exhibition held in 1984-1985 at the Museum of Modern Art in New York (1988: ch. 9, "Histories of the Tribal and the Modern»), an important essay by MacGaffey (1998), and several contributions to Szalay 1990.

12. It is interesting to observe that many travellers were less reluctant to speak of art when it came to verbal and musical performances or «body arts ", such as coiffures and ornamental scarification. 13. Hence recognition of materiality is not to be confused with reification. About connections between objects, objectification, and objectivity, see Fabian 1994 (reprinted in 2001 : ch. 1).

14. See the collection of essays edited by Howes (1991), and especially the work of Taussig (1987, 1993), as well as studies by Kramer (1993) and Stoller (1995), to name but a few of the most influential titles in a growing literature. 
things in mind when we speak of ethnic artefacts. On the other hand, we would not be talking at all about ethnic artefacts if they were not part of our environment. This they are, as collections and displays, on the condition that their materiality be severely restricted if materiality means cultural materiality, culturally informed experiences of and with the body. Who would think of making butter in a churn from Transsylvania or sleeping with a neck-rest from the Sepik river? Even in a modern museum that does without vitrines, who, with rare exceptions, is allowed to touch or smell these objects ? Though often aggressively displayed, exhibits of objects actually frustrate our bodily desire to explore their materiality. Could this account for some of the abuse heaped on museum displays? It is as if just enough materiality were preserved for artefacts to make them count, either as commodities in a market, or as signs in systems of representation.

Of course, much the same goes for ethnic dances, songs, poems, and stories. They are essentially performances and would, therefore, seem inextricable from context and materiality. Nevertheless, by being made into audio- and video-recordings, texts, musical scores, images, or choreographic styles, they can serve the functions of artefacts (such as being used as vehicles for nationalist propaganda, or being marketed by the entertainment or publishing industry).

Dematerialization (which demands removal of the artefact from its original context and abstinence from any desire to restitute to it its materiality) would also seem to be what makes de-localization possible and thus allows artefacts that were produced (and may be used) locally, to become part of what we now call globalization. That Marx formulated his theories of commodity circulation, that (proto-)anthropologists began to construe their diffusionist world history, and museums to hoard their collections of ethnic artefacts at about the same time, is fascinating but, in the end, not really surprising. Dematerialization of material things was the common denominator.

There are other avenues that tempt one to speculate about commonalities and differences between ethnic artefacts and ethnographic objects. One of them would be to follow their different integration into the urbanbourgeois living space (spanning the gamut, say, from Freud's study to Picasso's atelier). We know a lot about the display of exotica in "Victorian " drawing rooms; we would like to know more about the conditions, and the moment, when peasant objects (scythes, plowshares, ceramics and textiles, religious statuary or paintings) became props of «interior decorating." Some of these developments in interior decorating started well before the period considered here (roughly between the onset of modern colonization of Africa and the First World War). Artefacts from China and 
from the British and Dutch Indies were collected and displayed well before either the modern ethnographic objects or the ethnic artifacts we are considering here.

What is the situation now? Intuitively we would expect that ways of exhibiting ethnic artefacts differ from those of displaying ethnographic objects, in museums as well as in private homes. But exactly what are these differences and what do they mean? Again, we know that one of the lines of demarcation is the one that separates crafts from art, or art from Art. But why should Dogon carved doors fetch prices at auctions that antiquarian dealers in Bauernbarock cannot dream of?

Yet another criterion of distinction may be operative in classifying artefacts. Ever since the beginning of material culture studies, many of these objects were classed under the rubric of technology. When does an artefact qualify as an instance of technology? When it has moving parts? But what about tools and weapons? Or pots and baskets? When does technology become art? I stop before this turns into a list of open questions which, I think, become more difficult to answer the closer we get to concrete artefacts, and it is the latter that occupy us here.

In concluding, I should like to ask : how do artefacts classified as ethnic or ethnographic relate to "Modern Culture » ? From a perspective informed by the history of anthropology, we cannot assume a kind of equivalence either between the two classes of objects or between the disciplines of folklore and ethnology (or ethnography), just because in both cases urban elites serving the culture of nation states made backward, marginal peoples, or backward parts of modern populations objects of study.

As I understand it, the scenario of a story eventually to be told would begin by revealing an opposition, in fact a contradiction, of two paradigms (sometimes coexisting in the head of one and the same thinker): the Enlightenment and its critique in Romantic thought. The former resolutely relies on science as discovery; in "natural history", history is nothing but evidence for the operation of immutable natural laws which can be discovered by observing what is hic et nunc as an instance of processes that move in irreversible physical time. Romantic thought restored history as the presence of the past, fondly remembered or painfully suffered, without which understanding of human culture could produce nothing but the sort of moral banalities expounded by "philosophical history". Folklore, and the practices of collecting ethnic artefacts that interest us here, started out, under the Romantic paradigm, as re-cognition, Wieder-Erkennen and Anerkennen of a past that was to be kept alive 
because it was felt that it was, or should be, a running source of present identity. That, in order to assure its academic recognition, folklore (Volkskunde) paid the price of deadeningly positivist, scientific methodologization is a different story. Anthropology/Ethnology (Völkerkunde), and the practices of collecting ethnographic objects, started out to serve (and continued to serve ever since) constructions of alterity. Under the Enlightenment paradigm, anthropology was to be scientific (no matter how unscientific its practices may have been) and to serve cognition that not only did not need re-cognition, but had to suppress recognition as a threat to objective distance whenever it may have imposed itself. Again, anthropology always included counter-positions and the question why in modern anthropology the balance eventually tipped in favor of the Enlightenment paradigm, at least until the recent postmodern upheavals in our discipline, are matters we cannot pursue here.

The scenario of my dilemma tale must, like all scenarios, simplify matters if the story is to be told at all. Any given school, national tradition, indeed, any given oeuvre has been eclectic, mixing elements of Enlightenment and Romantic thought. Nonetheless, we should keep the horns of the dilemma apart, if only to make it possible to perceive what is crucial about relations between modern constructions of identity and alterity : though the concepts should logically be complementary, historically and politically they are not. The more we get to know about its history, the clearer it becomes that modern constructions of alterity emerged when spatial and temporal distancing merged to form the basis of a denial of recognition (of contemporaneity, or modernity). Intellectually, politically, and economically, identity became identity at the expense of Others.

We would be unable to understand the urgency or thoroughness, in fact, the notorious callousness, of such constructions of the Other, if we failed to recognize them as connected to a process of nation-state formation (and, of course, its capitalist economic, military, and technological underpinnings). It is by asking ourselves to what extent this, the modern, constellation is still in place, or whether and to what extent it has begun to fall apart in a process of globalization, signalled by the breakdown, or breaking up, of empires, that we will come to understand radical change in our conceptions also of the ethnic artefact. To anchor such understanding in highly general and global developments requires a renewed attention to objects as they exist in their materiality and local contexts. At the present, neither folklore nor cultural anthropology are well equipped to meet these challenges ${ }^{15}$.

15. Though there are impressive attempts to show that, in this case, anthropology can meet the challenge : see Hannertz 1992 and Augé 1994. Of special interest, because it focuses on objects and identity, is an essay by Bogumil Jewsiewicki (1995). 
From the vantage point of my own work, two discourses and research fields, because they assume a decidedly trans- or post-national perspective, may provide us with the required new approaches to ethnic artefacts and ethnographic objects : peasant studies and the study of popular culture. Let me briefly comment on the latter, if only because it has occupied me for some time, while I cannot claim any research experience in the former ${ }^{16}$. Though the concept of popular culture may appear to be as heterogenous and confused as the phenomena it describes, it has its uses if and when it serves the critique of the classical concept of culture. In modern anthropological (and related) theorizing, culture was established as a concept of identity stressing systemic integration, purity, adherence to shared values and beliefs, and conformity in conduct and outlook. There can be no doubt that the practical, political context of such a concept has been the nation-state. Nor can there be any doubt that propagating a concept of culture which the nation-state generated means propagating a state of affairs that no longer exists. Above all, in promoting attention to the precariousness of cultural creations, to their embeddedness in performances, and their inherently contemporary outlook, the concept of popular culture could prove useful in exploring the ethnic artefact in modern culture. If that is so, we should be prepared to struggle, once again, with recognition. Ethnic artefacts will never be objects that are simply there. Where? Conversely, objects do not qualify as ethnic artefacts simply because they belong to some place and to someone. To what place and to whom?

KEYWORDS/MOTS CLÉS: objects/objets - material culture/culture matérielle - knowledge and recognition/connaissance et reconnaissance - exploration - collecting/collecter.

16. One of the most influential works to emerge from peasant studies is Scott (1985). Among popular culture studies see Rowe \& Schelling (1991) and a summary of my own work on the subject (Fabian 1998c). 
Appadurai, Arjun, ed.

1986 The Social Life of Things. Commodities in Cultural Perspective. Cambridge,

Cambridge University Press.

\section{Augé, Marc}

1994 Pour une anthropologie des mondes contemporains. Paris, Aubier.

\section{Clifford, James}

1985 "Objects and Selves: An Afterword", in George W. Stocking, ed., Objects and Others. Essays on Museums and Material Culture. Madison, University of Wisconsin Press : 236-246.

1988 The Predicament of Culture. Twentieth-Century Ethnography, Literature, and Art. Cambridge, MA, Harvard University Press.

\section{Dias, Nélia}

1994 «Looking at Objects : Memory and Knowledge in Nineteenth-Century Ethnographic Displays », in George Robertson et al., Travellers' Tales. London, Routledge : 164-176.

Dilley, Roy, ed.

1999 The Problem of Context. Oxford, Berghahn.

\section{Fabian, Johannes}

1983 Time and the Other: How Anthropology Makes its Object. New York, Columbia University Press.

1991 Time and the Work of Anthropology: Critical Essays 1971-1991. London, Harwood Academic Publishers.

1994 «Ethnographic Objectivity Revisited: From Rigor to Vigor ", in Allan Megill, ed., Rethinking Objectivity. Durham-London, Duke University Press : 81-108.

1995 «On Ethnographic

Misunderstanding and the Perils of Context ", American Anthropologist 97 : 1-10.
1996 Remembering the Present: Painting and Popular History in Zaire. Berkeley, University of California Press.

1998a «Etnické artefakty a etnografické objekty : o sposnávaní vecí » ["Ethnic artefacts and ethnographic objects : on recognizing things »] Slovensky národopis [Slovak Ethnology] 46 : 302-313.

1998b "Curios and Curiosity: Notes on Reading Torday and Frobenius ", in Enid Schildkrout \& Curtis A. Keim, eds, The Scramble for Art in Central Africa. Cambridge, Cambridge University Press : 79-108.

1998c Moments of Freedom: Anthropology and Popular Culture. Charlottesville, University Press of Virginia.

1999 "Remembering the Other :

Knowledge and Recognition in the Exploration of Central Africa ", Critical Inquiry 26 : 49-69.

2000 Out of Our Minds: Reason and Madness in the Exploration of Central Africa. Berkeley, University of California Press. 2001 Anthropology with an Attitude. Critical Essays. Stanford, Stanford University Press.

2002 «Ethnische Artefakte und ethnographische Objekte : über das Erkennen von Dingen ", in Ákos Moravánszky, ed., Das Entfernte Dorf. Moderne Kunst und ethnischer Artefakt. Vienna, Böhlan : 21-39.

\section{Fabian, Johannes \& Ilona Szombati-Fabian} 1980 «Folk Art from an Anthropological Perspective ", in Ian M. G. Quimby \& Scott T. Swank, eds, Perspectives on American Folk Art. New York, Norton : 247-292.

\section{Frobenius, Leo}

1907 Im Schatten des Kongostaates. Bericht über den Verlauf der ersten Reisen der DIAFE von 1904-1906, über deren Forschungen und Beobachtungen auf geographischem und kolonialwirtschaftlichem Gebiet. Berlin, Georg Reimer. 


\section{Hannertz, Ulf}

1992 Cultural Complexity. Studies in the Social Organization of Meaning. New York, Columbia University Press.

Howes, David, ed.

1991 The Varieties of Sensory Experience. A Sourcebook in the Anthropology of the Senses. Toronto, University of Toronto Press.

Jewsiewicki, Bogumil

1995 "The Identity of Memory and the Memory of Identity in the Age of Commodification and Democratization ", Social Identities 1 : 227-262.

Kirschenblatt-Gimblett, Barbara

1998 Destination Culture. Tourism, Museums, and Heritage. Berkeley, University of California Press.

Kohl, Karl-Heinz, ed.

1996 Das exotische Ding. Geschichten einer Sammlung. Mainz, Institut für Ethnologie und Afrika-Studien.

\section{Kramer, Fritz W.}

1987 Der Rote Fes. Über Besessenheit und Kunst in Afrika. Frankfurt, Athenäum. 1990 "Geist, Bild, Realität », in Miklós Szalay, ed., Der Sinn des Schönen. Ästhetik, Soziologie und Geschichte der afrikanischen Kunst. Munich, Trickster : 33-47.

1993 The Red Fez. Art and Spirit Possession in Africa. London, Verso.

\section{MacGaffey, Wyatt}

1998 " "Magic, or as We Usually Say, Art". A Framework for Comparing European and African Art ", in Enid Schildkrout \& Curtis A. Keim, eds, The Scramble for Art in Central Africa. Cambridge, Cambridge University Press : 217-235.

Miller, Daniel

1987 Material Culture and Mass Consumption. Oxford, Basil Blackwell.

\section{Pietz, William}

1985 "The Problem of the Fetish, I", Res 9: 5-17.

1987 "The Problem of the Fetish, II : The Origin of the Fetish ", Res 13:23-45. 1988 " The Problem of the Fetish, IIIa: Bosman's Guinea and the Enlightenment Theory of Fetishism ", Res $16: 105-123$.

\section{Pomian, Krysztof}

1987 Collectionneurs, amateurs et curieux.

Paris, Venise, XVI ${ }^{e}$-XVIII siècle. Paris, Gallimard.

Rowe, William \& Vivian Schelling

1991 Memory and Modernity. Popular Culture in Latin America. London, Verso.

Schildkrout, Enid \& Curtis A. Keim 1990 African Reflections. Art from Northeastern Zaire. New York, Museum of Natural History.

Schildkrout, Enid \& Curtis A. Keim, eds 1998 The Scramble for Art in Central Africa. Cambridge, Cambridge University Press.

Scott, James C.

1985 Weapons of the Weak. The Everyday Forms of Peasant Resistance. New Haven, CT, Yale University Press.

Stagl, Justin

1995 A History of Curiosity. The Theory of Travel 1550-1800. Chur, Harwood Academic Publishers.

Stocking, George W., ed.

1985 Objects and Others. Essays on Museums and Material Culture. Madison, University of Wisconsin Press.

Stoller, Paul

1995 Embodying Colonial Memories. Spirit Possession, Power and the Hauka in West Africa. London, Routledge. 
Szalay, Miklós, ed.
1990 Der Sinn des Schönen. Ästhetik, Soziologie und Geschichte der afrikanischen Kunst. Munich, Trickster.

\section{Taussig, Michael}

1987 Shamanism, Colonialism, and the Wild Man. Chicago, University of Chicago Press.

1993 Mimesis and Alterity. A Particular History of the Senses. London, Routledge.

\section{Thomas, Nicholas}

1991 Entangled Objects. Exchange, Material Culture and Colonialism in the Pacific. Cambridge, MA, Harvard University Press.

\section{Torday, Emil}

1925 On the Trail of the Bushongo. An Account of a Remarkable \& Hitherto Unknown African People, Their Origin, Art, High Social \& Political Organization \& Culture, Derived from the Author's Personal Experience Amongst Them. London, Seely, Service \& Co.

\section{RÉSUMÉ/ABSTRACT}

Johannes Fabian, On Recognizing Things: The "Ethnic Artefact» and the "Ethnographic Object ». - In this paper, travelogues and scientific reports on the exploration of Central Africa (ca 1875-1914) are read against a background of renewed interest in the anthropology of material culture. Of special interest is what these sources reveal about the epistemic, political, and economic conditions of collecting "ethnographic objects". Concentrating on the concept of recognition and its denial, the paper argues that objects found their place in Western museums and schemes of interpretation to the extent that they were dematerialized; decontextualization was constitutive of ethnographic objects and their collection. Comparing ethnographic objects with ethnic artefacts, commonalities and differences are shown to have been rooted in contrasting, yet inextricably linked, projects of creating identity as well as alterity.
Johannes Fabian, Reconnaître les choses : « artefact ethnique » et "objet ethnographique ». Cet article se propose de relire les récits de voyage et rapports scientifiques ayant trait à l'exploration de l'Afrique centrale (ca 18751914) en s'appuyant sur le nouvel intérêt qui s'est fait jour en anthropologie pour les cultures matérielles. Ces sources sont d'une importance capitale pour ce qui concerne les conditions économiques, politiques et épistémiques qui ont présidé à la collecte d'objets ethnographiques. Envisageant la notion problématique de re-connaissance, cet article s'attache à montrer que ces objets ou collections ethnographiques ne prennent place dans les musées occidentaux et ne trouvent sens dans les grilles d'interprétation qu'au prix d'une dématérialisation, c'est-à-dire d'une décontextualisation. En les comparant aux artefacts ethniques, les composants communs ou différences paraissent inextricablement liés à des projets contrastés de création d'identité aussi bien que d'affirmation de l'altérité. 